І. Ф. Бєленічев, О. Г. Алієва

\title{
Нові мішені фармакологічної корекції когнітивних розладів за умов пренатальної дії гіпоксії
}

\author{
Запорізький державний медичний університет
}

Ключові слова: пренатальна гіпоксія, ендогенна нейропротекція, білки теплового шоку HSP70, індукований гіпоксією фактор HIF-1 $\alpha$

Характер перебігу періоду внутрішньоутробного розвитку плода та періоду новонародженості значною мірою визначає майбутнє здоров'я й якість життя людини. Гестаційні фактори відіграють вирішальну роль у формуванні структур мозку, які братимуть участь у когнітивних функціях, включаючи навчання та пам'ять, формувати життєвий досвід і характер людини [1]. Проблема пренатального ураження центральної нервової системи (ЦНС) у дітей у сучасній медицині займає одне з провідних місць, а пренатальна гіпоксія є основною причиною пренатальних патологій ЦНС і смертності новонароджених дітей [2].

У структурі смертності новонароджених гіпоксія займає друге місце після недоношеності. 60-80 \% усіх захворювань ЦНС дитячого віку пов'язано 3 пренатальною гіпоксією [3]. За даними літератури, близько $23 \%$ дитячої смертності в усьому світі (це 0,7-1,2 млн дітей на рік) зареєстровано як результат пренатальної гіпоксії, 0,5 млн дітей стають інвалідами [4] (рис. 1).

У пацієнтів, які перенесли хронічну антенатальную гіпоксію, у 5-10 \% немовлят відзначається стійкий моторний дефіцит, а в 20-50 \% - сенсорні або когнітивні порушення, що зберігаються й у підлітковому віці [5].

Останніми роками значні зусилля науковців спрямовані на вивчення механізмів перинатальних гіпоксично-ішемічних ушкоджень головного

(с) Колектив авторів, 2019 мозку й, як наслідок, порушень реалізації когнітивних функцій [6]. Когнітивні функції є найскладніше організованими, що забезпечують адаптацію суб'єкта до фізичних i соціальних умов середовища проживання. Реалізація когнітивних функцій вимагає складної взаємодії всіх структур головного мозку. Гіпоксичні зміни в нервових клітинах у період активного розвитку мозку проявляються насамперед порушеннями цих функцій. Перелік психоневрологічних розладів, пов'язаних 3 гіпоксичними ушкодженнями головного мозку, надзвичайно широкий - від затримки психомовного та моторного розвитку до важких форм дитячого церебрального паралічу, що супроводжується розумовою недостатністю, руховими розладами, судомами [7].

Незважаючи на багаторічний пошук способів корекції постгіпоксичних порушень головного мозку, ефективної терапії гіпоксично-ішемічних ушкоджень головного мозку перинатального періоду сьогодні досі не існує. Терапія

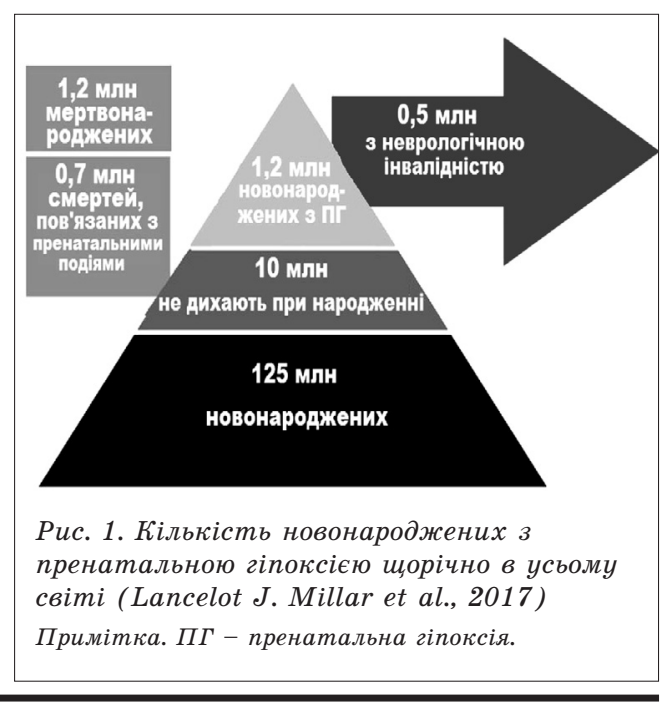

Фармакологія та лікарська токсикологія, Том 13, № 4/2019

ISSN 2227-7943. Pharmacology and Drug Toxicology, 2019, 13 (4), 235-248 
гіпоксично-ішемічних ушкоджень головного мозку пренатального періоду насамперед спрямована на корекцію гомеостазу, нормалізацію метаболізму нервової тканини та підвищення їі стійкості до гіпоксії, а також судинну терапію та лікування за синдромологічним принципом [5].

Розробка нових шляхів фармакологічної корекції порушень нервової системи після дії пренатальної гіпоксії є пріоритетним завданням для науковопрактичних досліджень.

Останні роки характеризуються суттєвими змінами у фармакологічній науці в стратегіях пошуку нових ефективних препаратів від громіздких досліджень властивостей і впливів нових речовин до пошуку мішеней фармакологічної корекції, впливаючи на які можливо швидко й ефективно нормалізувати функції клітин і тканин. Для реалізації цієї стратегії необхідно глибоке розуміння механізмів, що призводять до патологічних змін. Комплексне всебічне вивчення механізмів гіпоксичного антенатального ураження головного мозку і постгіпоксичних нейрональних наслідків дозволить прогнозувати й мінімізувати незворотні зміни в головному мозку, визначити структурні та молекулярні детермінанти - потенційні мішені фармакологічної корекції, i, тим самим, визначити основні напрями пошуку i створення найефективніших лікарських засобів. Оптимізація фармакологічних стратегій, спрямованих на визначення нових мішеній для відновлення тканин мозку після пренатальної дії гіпоксії, є актуальною, обгрунтованою, необхідною для теоретичної та практичної медицини.

Хронічна гіпоксія плода - це стан тривалого й постійного дефіциту кисню у плода внаслідок різних причин, найпоширенішою 3 яких є фетоплацентарна недостатність, що пов'язана 3 порушенням функції плаценти [8]. Хронічна гіпоксія призводить до зменшення розмірів і маси плода, викликає суттєві зміни в розвитку ЦНС (зменшення загального обсягу мозку, зменшення числа нервових клітин, порушення мієлінізації) [9], що надалі призводить до віддалених функціональних наслідків, таких як когнітивні порушення, церебральний параліч, серцево-судинні захворювання, гіпертензія, епілепсія $[10,11]$. Найвразливішими до гіпоксичних пошкоджень є зони мозку, які контролюють рух, такі як моторна кора, базальні ганглії, гіпокамп, мозочок [12-16].

Аналіз літератури з досліджень молекулярних механізмів пренатальної гіпоксії показав, що в основі гіпоксично-ішемічних уражень головного мозку новонароджених лежать: цереброваскулярні розлади та порушення механізму авторегуляції мозкового кровообігу, метаболічна катастрофа, пусковим механізмом якої є дефіцит кисню, а факторами, що безпосередньо пошкоджують мозок, є продукти спотвореного метаболізму [2, 17-20]. У більшості випадків причиною виникнення гіпоксичного стану плода називають плацентарну недостатність, хвороби матері, інфекційні процеси [21-24].

Мозок, що розвивається, є дуже чутливим до гіпоксичного пошкодження, тому що порівняно з іншими органами та тканинами, його потреба в кисні дуже велика [25]. Гіпоксія активізує різні цитотоксичні агенти та шляхи клітинної загибелі, що призводять до пошкодження мозку [26].

У літературі описані механізми клітинної загибелі за експериментального ураження головного мозку новонароджених. Запропонована Portera-Cailliau зі співавт. концепція континуума в своїй первісній формі характеризує загибель клітин у вигляді лінійного спектра з апоптозом і некрозом у крайніх точках i різними синкретичними гібридними формами між ними [27]. Згодом Frances J. Northington зі співавт. виявили, що ця концепція повністю відповідає процесам, які протікають у мозку новонароджених гризунів 3 пренатальною гіпоксією в експерименті, за цих умов класичні апоптотичні та класичні некротичні клітини виявлялися в суміші 3 різними гібридними формами [28] (рис. 2.)

Натепер відомо, що основними механізмами порушень за пренатальної гіпоксії є ексайтотоксичність, 


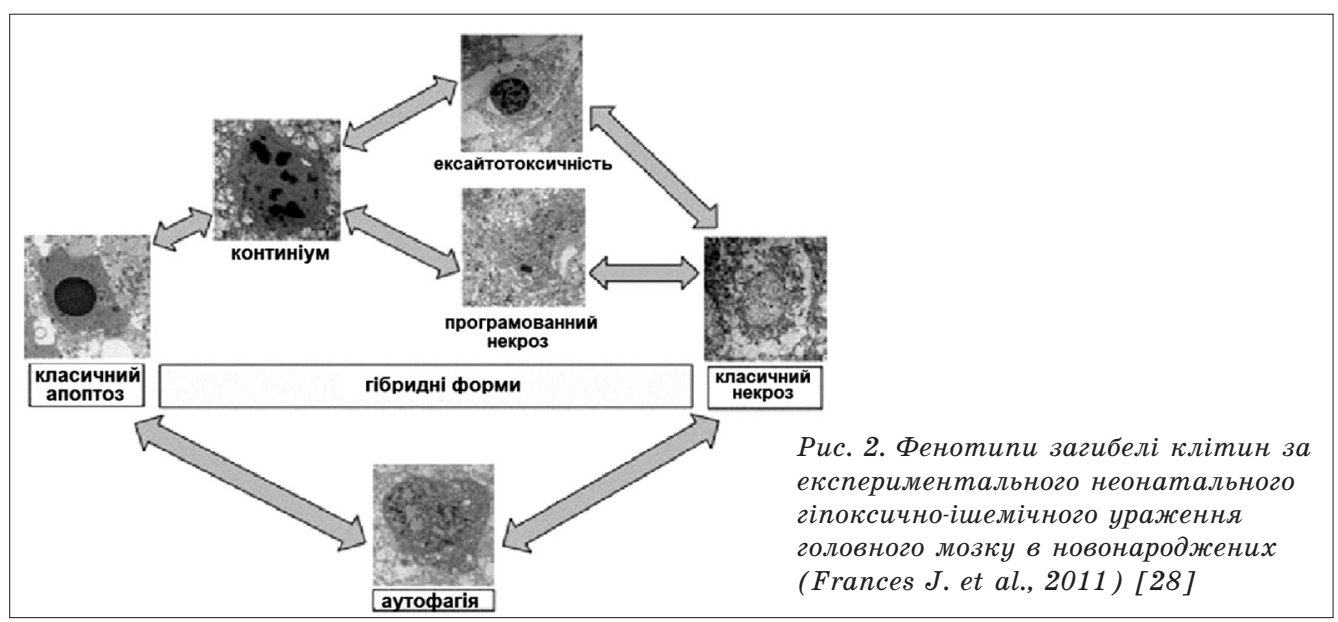

окиснювальний стрес і запалення [2, 8, 29, 30].

Ексайтотоксичність виникає в результаті надмірної або тривалої активації рецепторів глутамату - основного збудливого нейромедіатора. Це веде до гіперактивації специфічних постсинаптичних рецепторів (NMDA- рецепторів) $\mathrm{i}$, як наслідок, до порушення проникності іонних каналів, що регулюють уміст іонів у поза- і внутрішньоклітинному просторі. Надмірне накопичення внутрішньоклітинного кальцію запускає каскад реакцій 3 роз'єднанням мітохондріального транспортного ланцюга, активацією протеолітичних ферментів і руйнуванням клітинних структур, веде до збільшення синтезу оксиду азоту, посилення перекисного окиснення ліпідів з наступним розвитком окисного стресу, порушенням синтезу нейротрофічних факторів, а також запуском апоптозу [31-33].

Глутаматна ексайтотоксичність призводить до нітрозуючого стресу. Токсичні побічні продукти метаболізму оксиду азоту, що утворюються в клітинах за допомогою NO-синтетази, поряд з реактивними формами кисню, зв'язуються 3 важливими макромолекулами й ушкоджують клітини [34]. Особливості розташування глутаматних синапсів i рання експресія глутаматних рецепторів у гіпокампі, корі й ядрах середнього мозку відповідають областям, що є найчутливішими до шкідливої дії пренатальної гіпоксії [35, 36].

Окиснювальний стрес відіграє важливу роль у нейродегенеративних про- цесах після дії хронічної пренатальної гіпоксії. Він викликається надмірним рівнем вільних радикалів, які виникають у результаті окиснювальних реакцій, що відбуваються в організмі. Це призводить до перекисного окиснення ліпідів мембран і надалі до загибелі клітини [37]. Гіперпродукція активних форм кисню в процесі окисного метаболізму призводить також до модифікації ДНК, експресії та синтезу білків, y тому числі c-fos, які викликають апоптоз. Системи антиоксидантного захисту організму містять ферменти (каталазу, супероксиддисмутазу та глутатіонпероксидазу) і неферментні антиоксиданти (глутатіон, токоферол, аскорбат). Незріла система антиоксидантного захисту мозку, що розвивається, також сприяє чутливості до окиснювального стресу. Важлива роль у захисті від шкідливої дії АФК належить глутатіоновій системі. Зниження рівня глутатіону в клітині призводить до зростання активності NO-синтетази, збільшення утворення АФК і перекисного окиснення ліпідів, збільшення ексайтотоксичної відповіді через NMDA-рецептори, дегенерації мітохондрій [38].

Запалення є основним компонентом ушкоджень нервової тканини за гіпокciï. Встановлено, що в разі гіпоксії клітини мікроглії активуються та мігрують у пошкоджені області. Вони виробляють запальні цитокіни, глутамат, оксид азоту та вільні радикали. У процесі запалення беруть участь й астроцити, знижуючи або порушуючи 
функції гематоенцефалічного бар'єра, що в підсумку призводить до пошкодження нейронів [39-41].

Молекулярні дослідження наслідків гіпоксії в новонароджених показали, що пошкодження мозку новонароджених докорінно відрізняються від пошкоджень нервової тканини в результаті ішемії в дорослих $[23,24$, $42,43]$.

Мозок новонародженого складається 3 клітин, які продовжують процес диференціювання й утворення міжнейронних зв'язків. У мозку новонароджених, що розвивається, ще присутня вентрикулярна гермінативна зона 3 проліферуючими нейробластами (рис. 3). Молоді та недиференційовані клітини більш схильні до дії пошкоджуючих агентів, ніж зрілі клітини [44].

У низці робіт відзначені різні концентрації та дії сигнальних молекул у мозку, який розвивається, у тому числі caspase-3 i HIF-1 [45-48].

Гіпоксична дія включає в клітинах нервової системи компенсаторно-пристосувальні механізми, що націлені на підвищення стійкості клітинних структур до дефіциту кисню. Нервові клітини мають здатність адаптуватися до змін діючих на них хімічних і фізичних факторів. Ендогенна нейропротекція та нейропластичність включають короткочасні та довготривалі реакції, що призводять до підвищення стійкості нервової тканини до пошкодження різної природи та відновлення функцій після порушень, викликаних будьякими агентами [49].
Адаптація нейронів до гіпоксії на клітинному та субклітинному рівнях контролюється насамперед специфічним транскрипційним фактором, індукованим гіпоксією в усіх тканинах (HIF-1 - hypoxia inducible factor). Транскрипційна система HIF-1 є одним 3 головних регуляторів адаптивних механізмів відповідей на гіпоксію на локальному та системному рівнях. Кінцевим результатом активації HIF-1 є збільшення надходження кисню в клітину [50-52].

HIF-1 є гетеродимерним редоксчутливим білком, що складається з двох субодиниць - HIF-1 $\alpha$ і HIF-1 $\beta$. За нормоксичних умов синтез HIF- $1 \alpha$ відбувається 3 невисокою швидкістю, і його вміст є мінімальним, тому що він зазнає швидкої убіквітинації та деградації протеасомами. За умов дефіциту кисню деградація HIF-1 $\alpha$ протеосомами знижується, що призводить до накопичення, активації HIF- $1 \alpha$, його транслокації в ядро, димеризації з HIF$1 \beta$ і конформаційних змін, утворення транскрипційного активного комплексу (HRE), що запускає активацію широкого спектра НIF-1-залежних адаптивних процесів, спрямованих на посилення синтезу білків ендогенної цитопротекції (рис. 4) [46, 53, 54].

HIF-1 регулює гени, відповідальні за синтез еритропоетину, фактора росту ендотелію судин і транспортера глюкози-1 (Glut-1) [ 55]. НIF відіграє вирішальну роль у стимулюванні розвитку судин і метаболічної адаптації в процесі розвитку головного мозку.

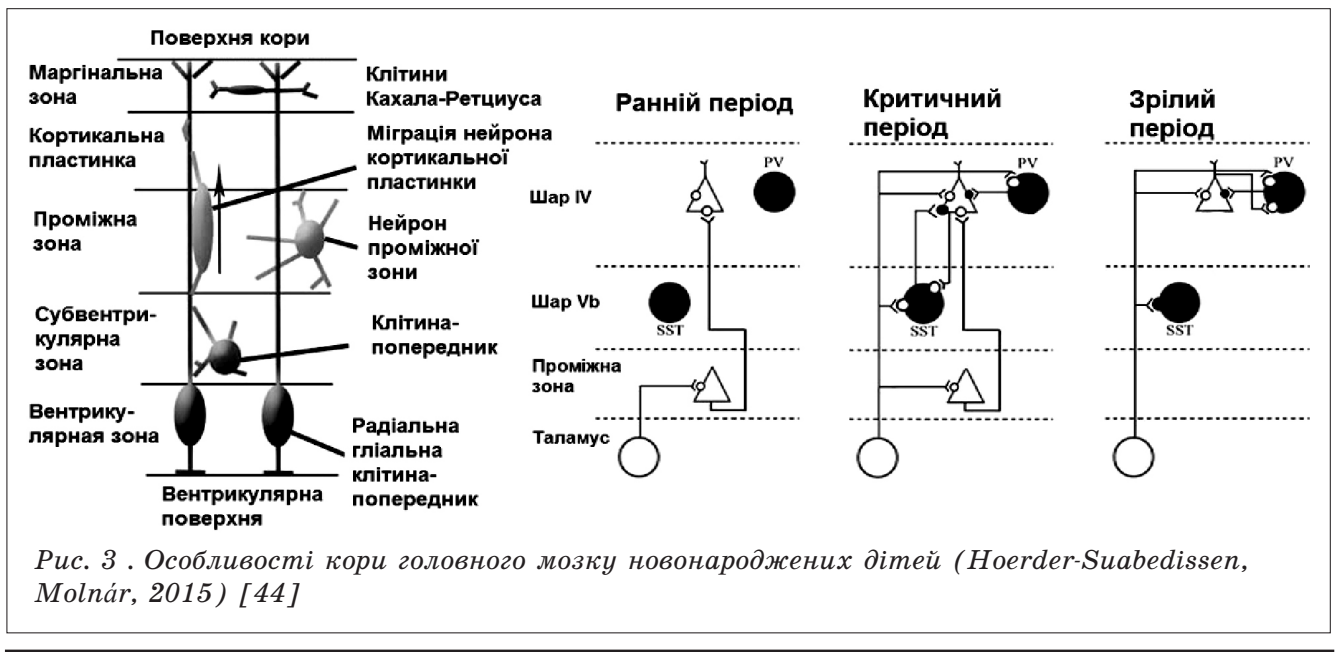




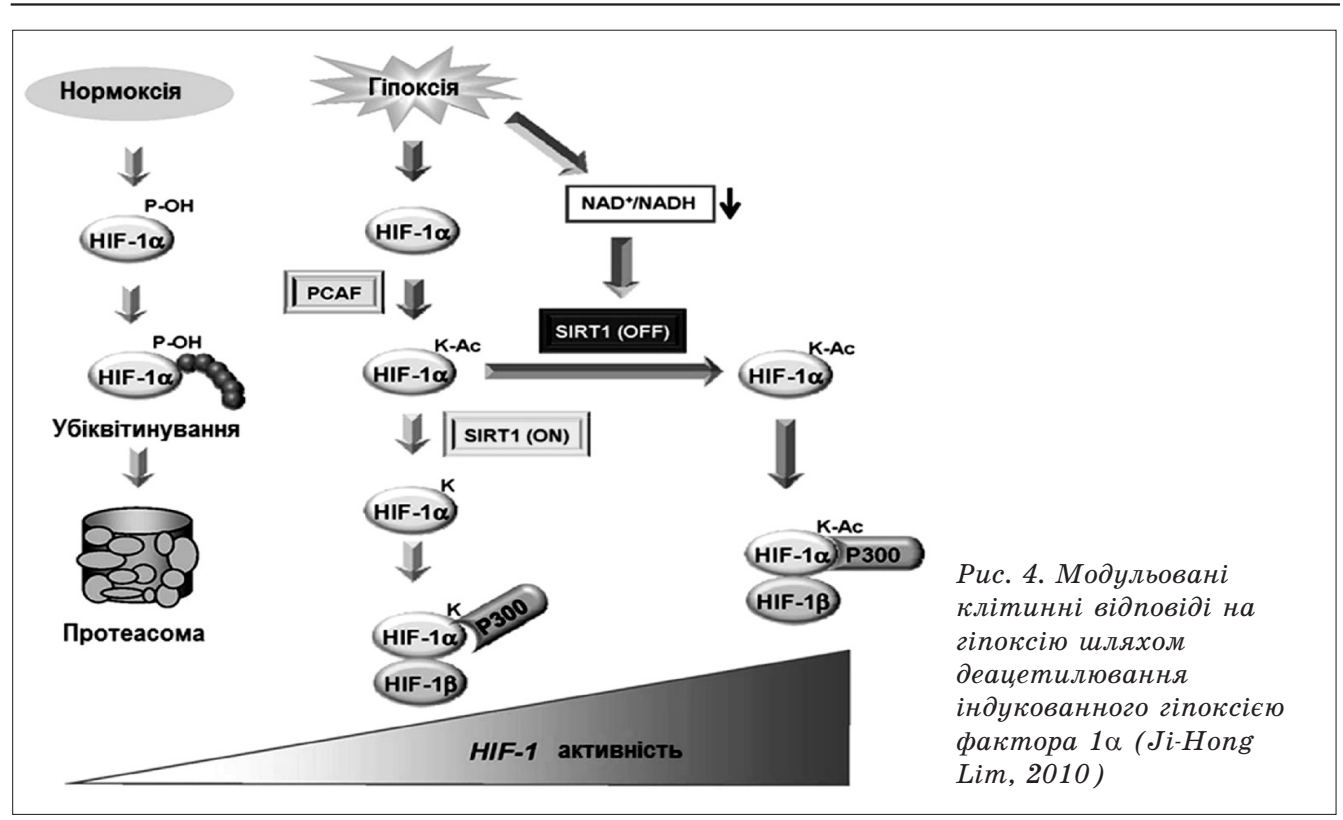

У роботах останніх років показано, що HIF-1 впливає на епігенетичні процеси в мозку, що розвивається, які можуть призвести до гіпоксично чутливого фенотипу [56]. Зміни в експресії генів, чутливих до гіпоксії, у пренатальному розвитку мають адаптивний характер, однак, їхні епігенетичні модифікації можуть призводити до негативних змін у розвитку нервової системи i, зокрема, лежати в основі розладів дефіциту уваги або гіперактивності в дітей [57].

Епігенетичні механізми, які запускаються за умов пренатальної гіпоксії, включають такі процеси, як метилювання ДНК і модифікацію гістонів, які регулюють згортання хроматину й активацію генів [58, 59].

Було встановлено, що у відповідь на внутрішньоутробну гіпоксію на пізніх термінах гестації в мозку, який розвивається, спостерігалася рання експресія генів залежних від гіпоксії факторів (HIF), ранніх генів (Fos, Jun, Bhlhb2, Egr1), факторів, що сприяють апоптозу (Bnip3, Dusp1, Ier3) і факторів пригнічення генів, що модулюють зв'язування та трансляцію РНК (Thap2, Rbm3, Lig4, Rbm12b) [60]. Зміни експресії генів, що є мішенями епігенетичних модифікацій (Fos, Bnip3), вказують на роль внутрішньоутробної гіпоксії в індукції епігенетичних механізмів у нервових клітинах, що розвиваються $[61,62]$.
Індуковані гіпоксією фактори транскрипції (HIF), особливо HIF-1 $\alpha$, $€$ ключовими молекулярними медіаторами транскрипційних реакцій, викликаних гіпоксією. HIF-1 $\alpha$ зв'язується 3 субстратами відповіді на гіпоксію (hypoxia response elements - HRE) y промоторній i енхансерній областях генів-мішеней, що сприяє формуванню гіпоксично-індукованного фенотипу [63]. У сучасній науковій літературі останніх років зустрічаються дані, які свідчать про те, що експресія HIF-1 $\alpha$ також може регулюватися епігенетичними механізмами. Промотор HIF-1 $\alpha$ має регіони, багаті CpG. Метилювання ДНК пригнічує експресію HIF-1 $\alpha$, a деметилювання шляхом пригнічення DNMT підсилює його експресію [64, 65]. Також є дані, що хроматин-ремоделюючий комплекс SWI/SNF є необхідним для опосередкування клітинних відповідей, викликаних гіпоксією, у тому числі HIF-1 $\alpha$ [66]. Накопичені сучасною наукою дані також підтверджують участь окремого класу малих некодуючих мікроРНК (miRNA) таких, як miR-23, miR-24, miR-26, miR-107, miR-210, miR-373 та ін., у посттранскрипційній регуляції генів-мішеней у відповідь на гіпоксію [67-69]. Багато з цих мікроРНК беруть участь у регуляції експресії HIF-1. Так, під час гіпоксії надлишкова експресія miR-200 збільшувала стабільність HIF-1 $\alpha$ шляхом 
впливу на PHD2 і гідроксилази для деградації протеосом HIF-1 $\alpha$ за нормоксичних умов [70]. Деякі з них самі $\epsilon$ мішенями HIF-1, такі як miR-210. MiR-210 і HIF характеризуються взаємним регулюючим впливом один на одного: експресія miR-210 регулюється HIF [71-73], та miR-210 також регулюе стабільність HIF [74]. Таким чином, miRNAs також можуть брати участь у відповіді нейрональних клітин на гіпоксію. $\mathrm{E}$ дані, що гіпоксія змінюе експресію miRNA у перицитах кори щура [75] і гіпокампі [76], що призводить до когнітивної дисфункції. Зміни в паттерні miRNA у мозку, який розвивається, після пренатальної гіпоксії $\mathrm{e}$ одним з факторів формування схильного до нейродегенерації фенотипу в більш пізньому віці. Кількісний аналіз мікроРНК у материнській крові зараз розглядається як потенційний інструмент для виявлення ризику гіпоксії плода [77].

Посттрансляційна стабільність HIF-1 контролюється за допомогою доменів пролілгідроксилази (PHD) i процесу убіквітинування, опосередкованого фактором VHL (von-Hippel-Lindautumour-suppressor). Дослідження останніх років показують, що експресія й активність PHD i VHL регулюється рівнем метилування їхніх промоторів [78, 79]. Було виявлено, що HDAC регулює експресію й активність VHL, що вказує на роль модифікації гістонів у стабільності HIF-1 $\alpha$ за гіпоксії [80].

Низка досліджень вказує на роль гіпоксії в перепрограмуванні розвитку клітин ембріонального мозку. Було встановлено, що рівень кисню є важливим фактором, необхідним для визначення перемикання диференціювання стовбурової нейральної клітини (NPC) під час розвитку мозку [81-83]. Метилування ДНК є ключовим фактором для диференціювання стовбурової клітини NPC в астроцити або нейрони, особливо в період активного диференціювання (у середині внутрішньоутробного розвитку), коли гени, що кодують типові маркери астроцитів, є гіперметильованими [84]. Встановлено, що шлях передачі сигналів Notch активується під час гіпоксії та взаємодіє з НIF-1 $\alpha$ для індук- ції експресії ядерного фактора транскрипції IA (NFIA). IA зв'язується 3 промоторами специфічних для астроцитів генів, таких як Gfap i S100 $\beta$. Це призводить до деметилування ДНК цих астроцит-специфічних генів та їхньої експресії [83, 84]. Зниження рівня кисню стимулююче впливає на диференціювання астроцитів у фетальному мозку, що призводить до зниження співвідношення нейрон-астроцити, що підтверджується роботами $[85,86]$. Відкриття епігенетичних впливів гіпоксії на розвиток нервових клітин і участі HIF-1 $\alpha$ у цих процесах дозволяе пояснити механізми виникнення великої групи когнітивних i моторних порушень у дітей після тривалого впливу внутрішньоутробної гіпоксії.

HIF-1 є важливим регулятором васкуляризації головного мозку. В експерименті з нульовою мутацією в локусі HIF-1 $\alpha$ за допомогою гомологічної рекомбінації в ембріональних стовбурових клітинах миші (ES), Райан і його колеги виявили порушення в розвитку нервової системи, відсутність васкуля-

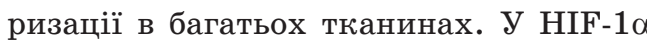
null - мутантних ембріонів експресія генів-мішеней HIF-1, таких як транспортер глюкози-1 (GLUT1), VEGF та ін., була значно знижена [87].

Однією з первинних реакцій геному клітин у відповідь на гіпоксичний стрес є індукція білка теплового шоку - Heat shock proteins (Hsp).

Білки теплового шоку 70 кДа (Hsp70) сприяють широкому спектру процесів згортання та складання знов синтезованих білків, рефолдингу неправильно згорнутих й агрегованих білків, мембранній транслокації органелярних i секреторних білків, а також контролю активності регуляторних білків [88]. У результаті дії гіпоксії розгорнуті білки накопичуються в цитоплазмі й індукують експресію шаперонів за допомогою сигнального шляху, який включає активацію HSF (фактора транскрипції теплового шоку) [89]. HSP70 є основним цитоплазматичним шапероном, викликаним стресом [90, 91]. Індукція HSP70 є показником цитоплазматичного накопичення білків не в нативному стані [92]. Нsp70 взаємодіють з іншими 
системами клітинних шаперонів, включаючи Hsp90, шапероніни Hsp60, невеликі білки теплового шоку і дезагрегази Hsp100, разом утворюючи динамічну та функціонально універсальну систему для згортання, розгортання, регуляції, націлювання, агрегації й дезагрегації, а також деградації білків (рис. 5) [93, 94].

Дефіцит кисню виснажує АТФ і змінює внутрішньоклітинний гомеостаз, таким чином відключаючи АТФзалежні системи контролю якості білка та включаючи молекулярні шаперони, ферменти згортання та компоненти розпаду білка під час і після гіпоксії [96]. Накопичення розгорнутих білків у нейронах $\epsilon$ ендогенним стимулятором молекулярних шаперонів за допомогою їхніх специфічних сигнальних шляхів реакції на стрес у різних субклітинних компартментах. $€$ доказаною дія HSP70 на стабілізацію індукованого гіпоксією фактора - HIF-1 $\beta$. За умов нормоксії HSP70 знаходиться в комплексі з HIF1. За умов гіпоксії HSP70 витісняється 3 комплексу з HIF-1 білком ARNT 3 подальшим здійсненням своєї шаперонної функції щодо HIF-1, крім того, ці білки здійснюють односпрямовану дію щодо протекції клітини від окисного стресу за гіпоксії. Дослідженнями останніх років була встановлена нейропротективна активність HSP70 і HIF-1, що спрямована на зниження явищ оксидативного стресу та мітохондріальної дисфункції $[97,98]$. Зокрема, було показано, що HSP70 запобігає апоптозу (рис. 6). Hsp70 може впливати на апоптоз через його взаємодію з сопапероном Bag-1, який, як відомо, взаємодіє 3 антиапоптотичним білком bcl-2. HSP70 безпосередньо зв'язується 3 фактором-1 (apaf-1), що активує апоптотичну протеазу i запобігає утворенню функціональної апоптосоми. Підвищений рівень HSP70 захищає клітини від цитотоксичності, викликаної дією гіпоксії [88, 93].

Суттєва роль HSP70 у гомеостазі $\mathrm{Ca}^{2+}$. Гіперекспресія HSP70 захищає нейрони від гіпоксичного пошкодження шляхом підтримки клітинного гомеостазу $\mathrm{Ca}^{2+}$. HSP70 зменшує зв'язок ендоплазматичного ретикулуму з мітохондріями, запобігає перевантаженню мітохондрій $\mathrm{Ca}^{2+}$ і зменшує загибель клітин після гіпоксії [99].

У роботі Eisuke Dohi et al. (2012 p.) було встановлено, що Hsp70 беруть участь в опосередкованій шапероном

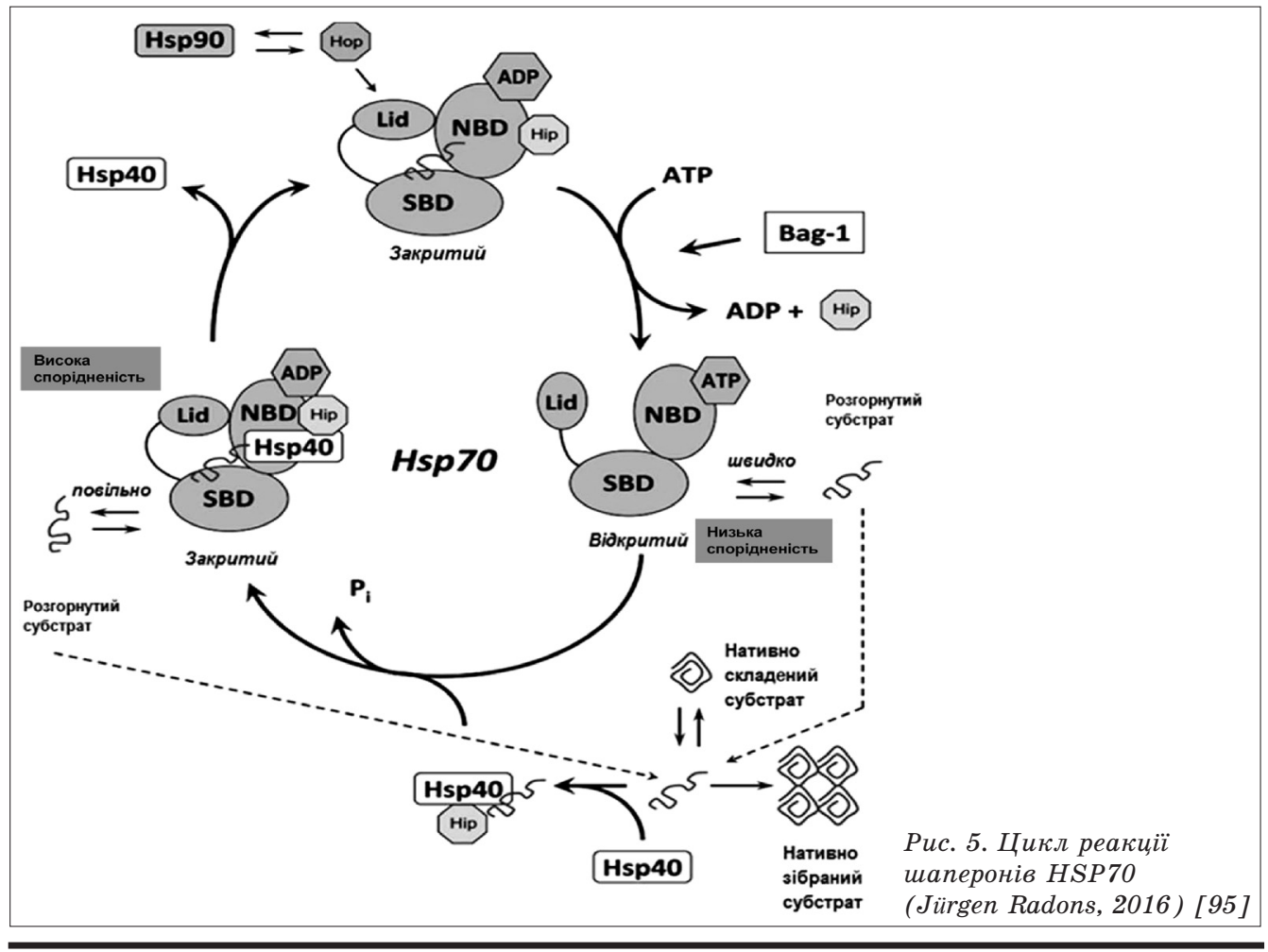

Фармакологія та лікарська токсикологія, Том 13, № 4/2019 


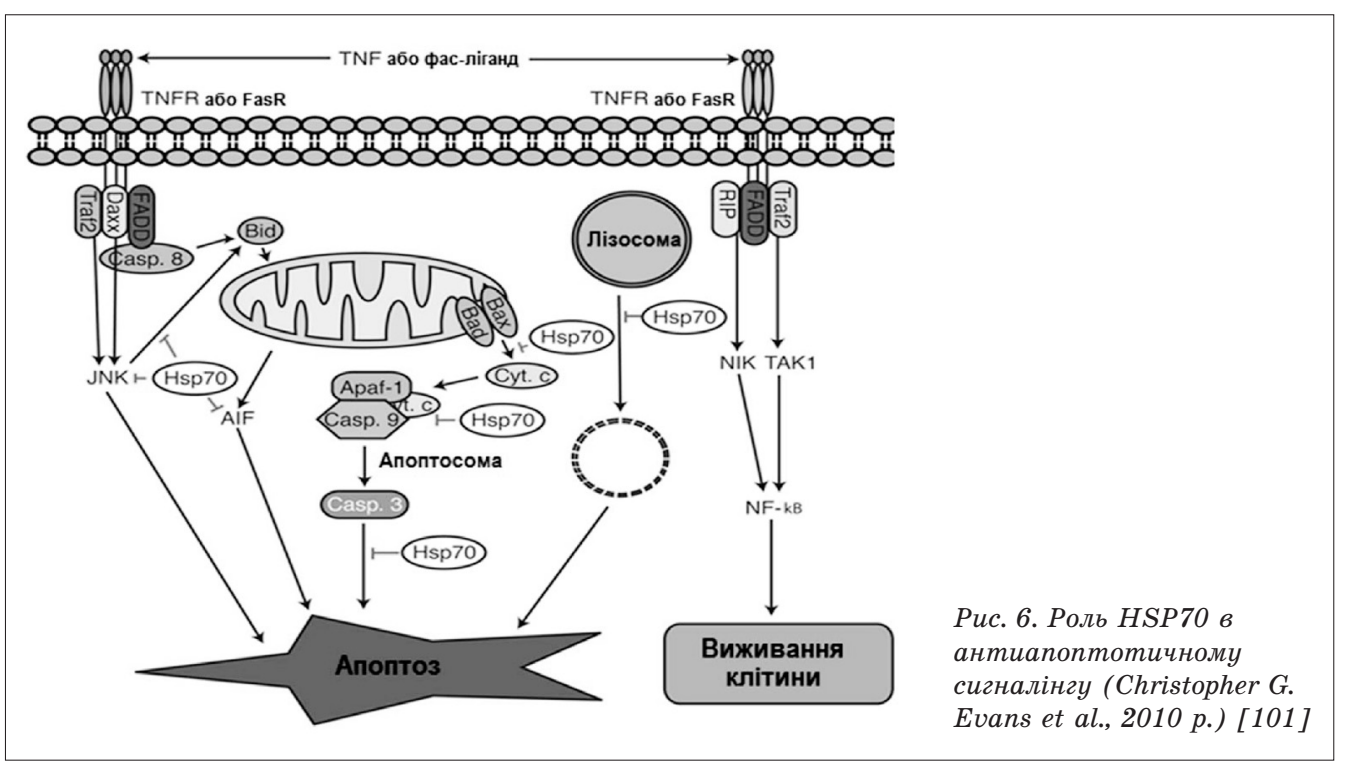

автофагії chaperone-mediated autophagy (CMA). Автофагія - це консервативний механізм, відповідальний за безперервний кліренс непотрібних органел або неправильно згорнутих білків у лізосомах. Натепер виділяють три типи автофагії, які розрізняються за механізмами доставки субстрату до лізосоми: макроавтофагії, мікроавтофагії й опосередковані шапероном автофагії (СМА). Серед різних типів CMA є унікальна система автофагії, яка вибірково розкладає субстрати, виявлені за допомогою білка теплового шоку 70 (HSP70). Вважається, що автофагія призводить до загибелі нейронів після гіпоксії головного мозку. Однак було продемонстровано, що HSP70-опосередкована автофагія активується під час гіпоксії та сприяє виживанню клітин за цих умов [100]

У роботах I. Riezzo et al. (2010 p.) було показано, що експресія HSP70 i HSP90 суттєво підвищується в нейронах на пізніх стадіях реакції у відповідь на дію внутрішньоутробної гіпокciï, тому вони можуть бути маркерами гіпоксичних порушень мозку новонароджених [102].

Останніми роками активно вивчаються можливості застосування екзогенного HSP70 для підвищення захисних і відновлюючих реакцій клітин. Так, в експериментах на моделі протеотоксичних захворювань (хвороба Хантингтона) встановлено, що препарат очищеного
HSP70 рятує клітини нейронального походження від апоптозу, викликаного токсичною дією агрегатів мутантних білків. Виявлений механізм захисної дії шаперона полягає в тому, що молекули білка проникають у клітини та завдяки своїй шаперонній активності знижують агрегаційну здатність ланцюгів поліглутаміну. Застосування шаперона в тваринних моделях призводило до значного поліпшення пам'яті в бульбектомованих тварин (модель хвороби Альцгеймера), що встановлено в дослідах 3 аналізу поведінкових реакцій. Уперше продемонстровано, що інтраназальне введення препарату HSP70 знижує пагубні наслідки посттравматичного синдрому на моделі неминучого стресу [103].

Деякими дослідженнями in vitro продемонстровано здатність SERM активувати синтез HSP 70-білка опосередковано, через активацію PER головного мозку [94, 98, 101].

Різноманітні хімічні субстрати взаємодіючих механізмів демонструють молеку-

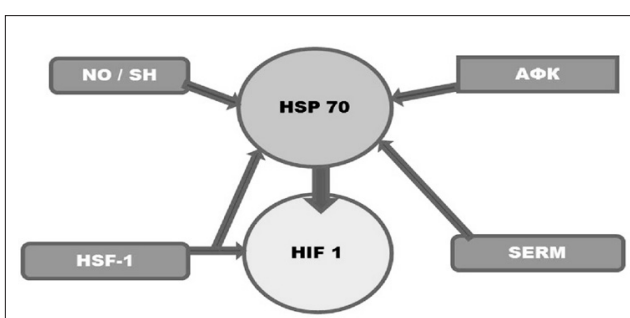

Рис. 7. Перспективні ланки - мішені нейропротекиї після дї пренатальної гіпоксії 
лярну складність пренатального пошкодження мозку після дії гіпоксії. Потенційний захисний вплив має бути спрямований на боротьбу зі спільними медіаторами цих каскадів, що відносяться до всіх механізмів. Потенційні мішені дії антигіпоксантів наведено на рисунку 7 .

\section{Висновки}

Таким чином, за умов дії хронічної пренатальной гіпоксії білки HSP70 i HIF-1 $\alpha$ є ключовими молекулярними учасниками процесів ендогенної нейропротекції через посилення синтезу антиоксидантних ферментів, стабілізацію окиснювально пошкоджених макромолекул, пряму антиапоптичну та мітопротективну дію. Тому, на нашу думку, пошук нових нейропротекторних засобів повинен бути направлений на активацію HSP70/HIF-1 $\alpha$-системи та використання агентів, здатних забезпечувати модуляцію генів, що кодують синтез білків HSP70 і HIF-1 $\alpha$.

1. Новые аспекты адаптации центральной нервной системы к пренатальной гипоксии. М. Д. Уразов, Т. А. Астраханова, А. В. Усенко и др. СТМ. 2018. Т. 10, № 4. С. 60-68.

2. Суханова Ю. А., Себенцова Е. А., Левицкая Н. Г. Острые и отставленные эффекты перинатального гипоксического повреждения мозга у детей и в модельных экспериментах на грызунах. Нейрохимия. 2016. Т. 33, № 4. С. 276-292.

3. Неонатология. А. К. Ткаченко, А. А. Устинович, А. В. Сукало и др. Москва : Высшая школа, 2017. $608 \mathrm{c}$.

4. Neonatal Hypoxia Ischaemia: Mechanisms, Models, and Therapeutic Challenges. L. J. Millar, L. Shi, A. Hoerder-Suabedissen etal. Front. Cell. Neurosci. 2017. https://doi.org/10.3389/fncel.2017.00078.

5. Абилитация младенцев с сочетанной перинатальной патологией: возможности персонализации подходов и методов. А. А. Баранов, Л. С. Намазова-Баранова, И. А. Беляева и др. Вопросы современной педиатрии. 2019. Т. 18, № 2. С. 91-100.

6. Treatment advances in neonatal neuroprotection and neurointensive care. M. V. Johnston, A. Fatemi, M. A. Wilson et al. Lancet Neurol. 2011. № 10. C. 372-382.

7. Ушкалова Е. А., Ушкалова А. В. Фармакотерапия когнитивных нарушений различного генеза: современное состояние и перспективные направления. РМЖ. 2014. № 22. С. 1613.

8. Стресс на ранних стадиях онтогенеза: пептидергическая коррекция. Н. А. Соколова, А. В. Граф, М. В. Маслова и др. Москва, 2016. 255 с.

9. Miller S. L., Huppi P. S., Mallard C. The consequences of fetal growth restriction on brain structure and neurodevelopmental outcome. J. Physiol. 2016. V. 594, № 4. P. 807-823.

10. Immunoreactivity of neurogenic factor in the guinea pig brain after prenatal hypoxia. Y. Chung, K. So, E. Kim et al. Ann. Anat. 2015. V. 200. P. 66-72.

11. Goyal R., Longo L. D. Fetal and Childhood Exposure to Phthalate Diesters and Cognitive Function in Children Up to 12 Years of Age: Taiwanese Maternal and Infant Cohort Study. PLoS One. 2015. V. 10, № 6. P. e0130739.

12. Head growth in infants with hypoxic-ischemic encephalopathy: correlation with neonatal magnetic resonance imaging. E. Mercuri, D. Ricci, F. M. Cowan et al. Pediatrics. 2000. V. 106, № 2 (P. 1). P. 235-243.

13. Patterns of brain injury in term neonatal encephalopathy. S. P. Miller, V. Ramaswamy, D. Michelson et al. J. Pediatr. 2005. V. 146. P. 453-460.

14. Oguni H., Sugama M., Osawa M. Symptomatic parieto-occipital epilepsy as sequela of perinatal asphyxia. Pediatr. Neurol. 2008. V. 38. P. 345-352.

15. Delayed neurological signs following isolated parasagittal injury in asphyxia at term. Y. Sato, M. Hayakawa, O. Iwata et al. Eur. J. Paediatr. Neurol. Soc. 2008. V. 12. P. 359-365.

16. Neonatal watershed brain injury on magnetic resonance imaging correlates with verbal IQ at 4 years. K. J. Steinman, M. L. Gorno-Tempini, D. V. Glidden et al. Pediatrics. 2009. V. 123. P. 1025-1030.

17. Ikonomidou C., Kaindl A. M. Neuronal death and oxidative stress in the developing brain. Antioxid. Redox Signal. 2011. V. 14. P. 1535-1550.

18. Inder T. E., Volpe J. J. Mechanisms of perinatal brain injury. Semin. Neonatol. 2000. V. 5. P. 3-16.

19. Ferriero D. M. Oxidant mechanisms in neonatal hypoxia-ischemia. Dev. Neurosci. 2001. V. 23. P. 198-202.

20. Miller S. L., Wallace E. M., Walker D. W. Antioxidant therapies: a potential role in perinatal medicine. Neuroendocrinology. 2012. V. 96. P. 13-23.

21. McQuillen P. S., Ferriero D. M. Selective vulnerability in the developing central nervous system. Pediatr. Neurol. 2004. V. 30. P. 227-235.

22. Treatment advances in neonatal neuroprotection and neurointensive care. M. V. Johnston, A. Fatemi, M. A. Wilson et al. F. Lancet Neurol. 2011. V. 10. P. 372-382.

23. Vulnerability of the developing brain to hypoxic-ischemic damage: contribution of the cerebral vasculature to injury and repair? A. A. Baburamani, C. J. Ek, D. W. Walker, M. Castillo-Melendez. Front. Physiol. 2013. V. 3. P. 424. 
24. Brain development in rodents and humans: identifying benchmarks of maturation and vulnerability to injury across species. B. D. Semple, K. Blomgren, K. Gimlin et al. Progress Neurobiol. 2013. V. 106. P. 1-16.

25. Sodium hydrosulfide prevents hypoxia-induced behavioral impairment in neonatal mice. Z. Wang, J. Zhan, X. Wang et al. Brain Res. 2013. V. 1538. P. 126-134.

26. Hossain M. A. Hypoxic-ischemic injury in neonatal brain: involvement of a novel neuronal molecule in neuronal cell death and potential target for neuroprotection. Int. J. Dev. Neurosci. 2008. V. 26, № 1. P. 93-101.

27. Portera-Cailliau C., Price D. L., Martin L. J. Excitotoxic neuronal death in the immature brain is an apoptosis-necrosis morphological continuum. J. Comp. Neurol. 1997. V. 378. P. 70-87.

28. Frances J., Raul Ch.-V., Lee J. M. Neuronal Cell Death in Neonatal Hypoxia-Ischemia. Ann. Neurol . 2011. V. 69, № 5. P. 743-758.

29. Vandenberg R. J., Ryan R. M. Mechanisms of glutamate transport. Physiol. Rev. 2013. V. 93 № 4. P. $1621-1657$.

30. Role of microglia adenosine $\mathrm{A}(2 \mathrm{~A})$ receptors in retinal and brain neurodegenerative diseases. $A$. $R$. Santiago, F. I. Baptista, P. F. Santos et al. Mediators Inflamm. 2014. URL: https://www.ncbi.nlm. nih. gov/ pmc/articles/PMC4124703.

31. Маслюкова А. В. Роль окислительного стресса и нарушений обмена глутамата в патогенезе повреждений головного мозга и печени плода, развивавшегося в условиях нарушенного маточно-плацентарного кровообращения: автореф. дисс. на соискание учен. степени канд. мед. наук: спец. 03.00.04 «Биологическая химия». ГОУ ВПО «Ивановская государственная медицинская академия». Челябинск, 2004. 22 с.

32. Томилова И. К. Биохимические механизмы повреждения головного мозга плода и новорожденного, развивавшегося в условиях нарушения маточно-плацентарного кровообращения, и их коррекция (экспериментальное исследование): дисс. на соискание уч. степени доктора мед. наук: спец. 03.00.04 «Биологическая химия». ГОУВПО «Российский государственный медицинский университет». Москва, 2012. 203 с.

33. Архипов В. И., Капралова М. В., Першина Е. В. Эксайтотоксичность и экспериментальные подходы к нейропротекции. Современные проблемы науки и образования. 2013. № 5. URL: http://www.science-education.ru/ru/article/view?id=10431.

34. Neonatal cerebral hypoxia-ischemia impairs plasticity in rat visual cortex. S. Failor, V. Nguyen, D. P. Darcy et al. J. Neurosci. 2010. V. 30. P. 81-92.

35. Lai M.-C., Yang S.-N. Perinatal Hypoxic-Ischemic Encephalopathy. J. Biomed. Biotechnol. 2011. URL: https://www.ncbi.nIm. nih.gov/ pmc/articles/PMC3010686.

36. Excitotoxicity as a Common Mechanism for Fetal Neuronal Injury with Hypoxia and Intrauterine Inflammation. I. Burd, J. Welling, G. Kannan et al. Adv. Pharmacol. 2016. V. 76. P. 85-101.

37. Molecular Mechanisms of Neonatal Brain Injury. C. Thornton, C. I. Rousset, A. Kichev et al. Neurol. Res. Int. 2012. URL: https://www.ncbi.nlm.nih.gov/pmc/articles/PMC3272851.

38. Горбачева С. В., Беленичев И. Ф. Показатели тиол-дисульфидной системы и нитрозативного стресса в нейронах в условиях моделирования глутаматной эксайтотоксичности in vitro и на фоне применения ингибиторов nos различной селективности. Мир Медицины и Биологии. 2015. № 4 (54), Ч. 2 . С. 112-116.

39. Agrawal V., Hirsch E. Intrauterine infection and preterm labor. Semin. Fetal Neonatal Med. 2012. V. 17. P. $12-19$.

40. The role of inflammation in perinatal brain injury. H. Hagberg, C. Mallard, D. M. Ferriero et al. Nat. Rev. Neurol. 2015. V. 11. P. 192-208.

41. Dammann O., Leviton A. Intermittent or sustained systemic inflammation and the preterm brain. Pediatr. Res. 2014. V. 75. P. 376-380.

42. McLean C., Ferriero D. Mechanisms of hypoxic -ischemic injury in the term infant. Semin. Perinatol. 2004. V. 28. P. 425-432.

43. Johnston M. V. Plasticity in the developing brain: implications for rehabilitation. Dev. Disab. Res. Rev. 2009. V. 15. P. 94-101.

44. Hoerder-Suabedissen A., Molnár Z. Morphology of mouse subplate cells with identified projection targets changes with age. J. Comp. Neurol. 2012. V. 520. P. 174-185.

45. The Role of NOX4 and TRX2 in Angiogenesis and Their Potential Cross-Talk. Ch. Chaofei, Li Li, J. Zh. Huanjiao et al. Antioxidants. 2017. V. 6, № 2. https://doi.org/10.3390/antiox6020042.

46. Qingdong K., Max Costa. Hypoxia-inducible factor-1 (HIF-1). Molecular Pharmacology. 2006. V. 70 , № 5. P. 1469-1480.

47. Gregg L. S., Nanduri R. P. The Role of Hypoxia-Inducible Factors in Oxygen Sensing by the Carotid Body. Advances in Experimental Medicine and Biology. 2012. V. 758. P. 1-5.

48. The Effects of Hypoxia and Inflammation on Synaptic Signaling in the CNS. M. Gatambwa, T. Ronan, L. Sinead et al. Brain Sci. 2016. V. 6, № 1. https://doi.org/10.3390/brainsci6010006.

49. Нейропротекция и нейропластичность. И. Ф. Беленичев, В. И. Черный, Е. А. Нагорная и др. Киев : Логос, 2015. 512 с.

50. Новиков В. Е., Левченкова О. С. Новые направления поиска лекарственных средств с антигипоксической активностью и мишени для их действия. Эксп. и клин. фармакология. 2013. Т. 76, № 5 . С. 37-47. 
51. Новиков В. Е., Левченкова О. С. Ингибиторы регуляторного фактора адаптации к гипоксии. Вестник СГМА. 2014. Т. 13, № 1. С. 40-45.

52. Myllyharju J., Koivunen P. Hypoxia-inducible factor prolyl 4-hydroxylases: common and specific roles. Biol. Chem. 2013. V. 394, № 4. P. 435-448.

53. Immunoreactivity of neurogenic factor in the guinea pig brain after prenatal hypoxia. Y. Chung, K. So, E. Kim et al. Ann. Anat. 2015. V. 200. P. 66-72.

54. Developmental study of the distribution of hypoxia-induced factor-1 alpha and microtubule-associated protein 2 in children's brainstem: comparison between controls and cases with signs of perinatal hypoxia. R. Coveñas, J. González-Fuentes, E. Rivas-Infante et al. Neurosci. 2014. V. 271. P. 77-98.

55. HIF-1alpha expression in the hippocampus and peripheral macrophages after glutamate-induced excitotoxicity. E. Vazquez-Valls, M. E. Flores-Soto, V. Chaparro-Huerta et al. J. Neuroimmunol. 2011. V. 238, № 1-2. P. 12-18.

56. Nalivaeva N. N., Turner A. J., Zhuravin I. A. Role of Prenatal Hypoxia in Brain Development, Cognitive Functions, and Neurodegeneration. Front. Neurosci. 2018. https://doi.org/10.3389/fnins.2018. 00825.

57. Pre-and Perinatal Ischemia-Hypoxia, the Ischemia-Hypoxia Response Pathway, and ADHD Risk. T. F. Smith, R. Schmidt-Kastner, J. E. McGeary et al. Behav. Genet. 2016. V. 46. P. 467-477.

58. Kato T., Iwamoto $K$. Comprehensive DNA methylation and hydroxymethylation analysis in the human brain and its implication in mental disorders. Neuropharmacology. 2014. V. 80. P. 133-139.

59. Tapias A., Wang Z. Q. Lysine acetylation and deacetylation in brain development and neuropathies. Genomics Proteomics Bioinformatics. 2017. V. 15. P. 19-36.

60. Trollmann R., Gassmann M. The role of hypoxia-inducible transcription factors in the hypoxic neonatal brain. Brain. Dev. 2009. V. 31. P. 503-509.

61. Epigenetic regulation of Dnmt3a and Arc gene expression after electroconvulsive stimulation in the rat. M. Dyrvig, C. R. Gøtzsche, D. P. Woldbye et al. Mol. Cell Neurosci. 2015. V. 67. P. 137-43.

62. Epigenetic regulation of Arc and c-Fos in the hippocampus after acute electroconvulsive stimulation in the rat. M. Dyrvig, H. H. Hansen, S. H. Christiansen [et al.]. Brain Res. Bull. 2012. V. 88, № 5. P. 507-513.

63. Epigenetics, the epicenter of the hypoxic response. J. A. Watson, C. J. Watson, A. McCann et al. Epigenetics: official journal of the DNA Methylation Society. 2010. V. 5. P. 293-296.

64. Tumor-associated CpG demethylation augments hypoxia-induced effects by positive autoregulation of HIF-1alpha. M. Koslowski, U. Luxemburger, O. Tureci et al. Oncogene. 2011. V. 30. P. 876-882.

65. DNA methylation-dependent suppression of HIF1A in an immature hematopoietic cell line HMC-1. A. Walczak-Drzewiecka, M. Ratajewski, L. Pulaski et al. Biochem. Biophys. Res. Commun. 2010. V. 391. P. $1028-1032$.

66. SWI/SNF regulates the cellular response to hypoxia. N. S. Kenneth, S. Mudie, van P. Uden et al. The Journal of biological chemistry. 2009. V. 284. P. 4123-4131.

67. MicroRNA regulation of DNA repair gene expression in hypoxic stress. M. E. Crosby, R. Kulshreshtha, M. Ivan et al. Cancer research. 2009. V. 69. P. 1221-1229.

68. Hypoxia-inducible mir-210 regulates normoxic gene expression involved in tumor initiation. X. Huang, L. Ding, K. L. Bennewith et al. Mol. Cell. 2009. V. 35. P. 856-867.

69. Four weeks of hypoxia training improves cutaneous microcirculation in trained rowers. Z. Meng, B. Gao, H. Gao et al. Physiol. Res. 2019. URL: http://www.biomed.cas.cz/physiolres/pdf/prepress/ 934175.pdf.

70. Immune mechanisms in cerebral ischemic tolerance. L. Garcia-Bonilla, C. Benakis, J. Moore et al. Frontiers in neuroscience. 2014. V. 8. P. 44

71. miR-210: the master hypoxamir. Y. C. Chan, J. Banerjee, S. Y. Choi et al. Microcirculation. 2012. V. 19. P. 215-223.

72. miR-210 is a target of hypoxia-inducible factors 1 and 2 in renal cancer, regulates ISCU and correlates with good prognosis. R. I. McCormick, C. Blick, J. Ragoussis et al. British journal of cancer. 2013. V. 108. P. 1133-1142.

73. Overexpression of miR-210, a downstream target of HIF1alpha, causes centrosome amplification in renal carcinoma cells. C. Nakada, Y. Tsukamoto, K. Matsuura et al. The Journal of pathology. 2011. V. 224. P. $280-288$.

74. Negative regulation of Hif1a expression and TH17 differentiation by the hypoxia-regulated microRNA miR-210. H. Wang, H. Flach, M. Onizawa et al. Nature immunology. 2014. V. 15. P. 393-401.

75. Hypoxia alters MicroRNA expression in rat cortical pericytes. J. S. Truettner, V. Katyshev, N. EsenBilgin et al. Microrna. 2013. V. 2. P. 32-44.

76. Intermittent hypoxia caused cognitive dysfunction relate to miRNAs dysregulation in hippocampus. H. Gao, Z. Han, S. Huang et al. Behav. Brain Res. 2017. V. 335. P. 80-87.

77. Circulating MicroRNAs in maternal blood as potential biomarkers for fetal hypoxia in-utero. C. L. Whitehead, W. T. The, S. P. Walker et al. PLOS ONE. 2013. URL: https://www.ncbi.nlm.nih. gov/pmc/ articles/PMC3839903.

78. The prolyl-hydroxylase EGLN3 and not EGLN1 is inactivated by methylation in plasma cell neoplasia. E. Hatzimichael, A. Dasoula, R. Shah et al. Eur. J. Haematol. 2010. V. 84. P. 47-51.

79. Nguyen M. P., Lee S., Lee Y. M. Epigenetic regulation of hypoxia inducible factor in diseases and therapeutic. Arch. Pharm. Res. 2013. V. 36. P. 252-263. 
80. The expression of VEGF receptor genes is concurrently influenced by epigenetic gene silencing of the genes and VEGF activation. J. Y. Kim, J. H. Hwang, W. Zhou et al. Epigenetics. 2009. V. 4. P. 313-321.

81. Qingyi M., Lubo Zhang. Epigenetic Programming of Hypoxic-Ischemic Encephalopathy in Response to Fetal Hypoxia. Prog. Neurobiol. 2015. V. 1. P. 28-48.

82. Hypoxia enhances the generation of induced pluripotent stem cells. Y. Yoshida, K. Takahashi, K. Okita et al. Cell stem cell. 2009. V. 5. P. 237-241.

83. Oxygen levels epigenetically regulate fate switching of neural precursor cells via hypoxia-inducible factor 1alpha-notch signal interaction in the developing brain. T. Mutoh, T. Sanosaka, K. Ito et al. Stem cells. 2012. V. 30. P. 561-569.

84. Committed neuronal precursors confer astrocytic potential on residual neural precursor cells. M. Namihira, J. Kohyama, K. Semi et al. Developmental cell. 2009. V. 16. P. 245-255.

85. Differential responses of hippocampal neurons and astrocytes to nicotine and hypoxia in the fetal guinea pig. T. Blutstein, M. A. Castello, S. S. Viechweg et al. Neurotox. Res. 2013. V. 24. P. 80-93.

86. Long-lasting changes in DNA methylation following short-term hypoxic exposure in primary hippocampal neuronal cultures. I. Hartley, F. F. Elkhoury, J. Heon Shin et al. PloS one. 2013. URL: https:// www.ncbi.nlm.nih.gov/pmc/articles/PMC3808424.

87. Ryan H. E., Lo J., Johnson R. S. HIF-1 alpha is required for solid tumor formation and embryonic vascularization. The EMBO journal. 1998. V. 17. P. 3005-3015.

88. Mayer M. P., Bukau B. Hsp70 chaperones: cellular functions and molecular mechanism. Cell Mol. Life Sci. 2005. V. 62, № 6. P. 670-684.

89. The human heat shock protein HSP70 interacts with HSF, the transcription factor that regulates heat shock gene expression. K. Abravaya, M. P. Myers, S. P. Murphy et al. Genes \& Development. 1992. V. 6 (7). P. $1153-1164$.

90. Pharmacological induction of the $70 \mathrm{kDa}$ heat shock protein protects against brain injury. N. Kim, J. Youl Kim, M. A. Yenari. Neuroscience. 2015. V. 284. P. 912-919.

91. Regulation of apoptotic and inflammatory cell signaling in cerebral ischemia: the complex roles of heat shock protein 70. R. Giffard, R. Han, J. Emery et al. Anesthesiol. 2008. V. 109. P. 339-348.

92. Naylor D. J., Hartl F. U. Contribution of molecular chaperones to protein folding in the cytoplasm of prokaryotic and eukaryotic cells. Biochem. Soc. Symp. 2001. V. 68. P. 45-68.

93. The Hsp70 chaperone network. R. Rosenzweig, N. B. Nillegoda, M. P. Mayer et al. Nature Reviews Molecular Cell Biology. 2019. URL: https://www.nature.com/articles/s41580-019-0133-3.

94. Jason C. Y. Mechanisms of the Hsp70 chaperone system. Biochem Cell Biol. 2010. V. 88, № 2. P. 291-300.

95. Radons J. The human HSP70 family of chaperones: where do we stand? Cell Stress and Chaperones. 2016. V. 21, № 3. P. 379-404.

96. Liu C., Hu B. Alterations of methylmaleimide-sensitive ATPase following transient cerebral ischemia. Neuroscience. 2004. V. 128, № 4. P. 767-774.

97. Нарушение шаперонной активности HSP-70 - возможный механизм формирования митохондриальной дисфункции. И. Ф. Беленичев, Ю. М. Колесник, С. В. Павлов и др. Нейрохимия. 2011. T. 28, № 4. С. 287-293.

98. Павлов С. В., Беленичев И. Ф. Молекулярно-биохимические аспекты нейропротективного действия селективного модулятора эстрогеновых рецепторов - тамоксифена в условиях моделирования острой церебральной ишемии. Нейрохимия. 2014. Т. 31, № 1. С. 36-41.

99. Heat shock protein 70 protects PC12 cells against ischemia-hypoxia/reoxygenation by maintaining intracellular $\mathrm{Ca}^{2+}$ homeostasis. Y. Liu, X. C. Wang, D. Hu et al. Neural Regeneration Research. 2016. V. 11, № 7. P. 1134-1140.

100. Hypoxic stress activates chaperone-mediated autophagy and modulates neuronal cell survival. E. Dohiab, S. Tanakaab, T. Sekia et al. Neurochemistry International. 2012. V. 60, № 4. P. 431-442.

101. Evans C. G., Chang L., Gestwicki J. E. Heat Shock Protein 70 (Hsp70) as an Emerging Drug Target. J. Med. Chem. 2010. V. 53, № 12. P. 4585-4602.

102. Riezzo I., Neri M., De Stefano F. The timing of perinatal hypoxia/ischemia events in term neonates: a retrospective autopsy study HSPs, ORP-150 and COX2 are reliable markers to classify acute, perinatal events. Diagn. Pathol. 2010. № 5. P. 49.

103. Гужова И. В. Механизмы работы шаперона Hsp70 в нормальных клетках и при клеточной патологии: автореф. дисс. на соискание учен. степени докт. биол. наук: спец. 03.00.25 «Гистология, цитология, клеточная биология». Инст. цитологии РАН, Санкт-Петербург. СанктПетербург, 2004. 22 с.

\section{І. Ф. Бєленічев, О. Г. Алієва \\ Нові мішені фармакологічної корекції когнітивних розладів за умов пренатальної дії гіпоксії}

В огляді наведено сучасні концепції механізмів пошкоджень клітин головного мозку за умов пренатального впливу хронічної гіпоксії. На основі сучасних даних про механізми адаптації організму до стану гіпоксії пропонуються нові перспективні напрями пошуку ефективних лікарських засобів для 
фармакологічної корекції наслідків пренатальної гіпоксії. Пренатальна гіпоксія є найпоширенішою причиною смертності та інвалідності новонароджених дітей. Хронічна пренатальна гіпоксія призводить до значних змін у розвитку когнітивних функцій у постнатальному періоді життя, які базуються на морфологічних змінах у структурах мозку, що беруть участь у навчанні та пам'яті.

Результати досліджень останніх років внесли великий вклад у розкриття механізмів формування стану гіпоксії різного генезу та індукованих нею порушень метаболічних і функціональних процесів на рівні клітини й субклітинних структур. Визначено ряд морфофункціональних детермінант (специфічні рецептори, регуляторні білки, внутрішньоклітинні ферменти, мітохондріальні іонні канали і т. д.), які беруть безпосередню участь у розвитку термінової та довготривалої адаптації клітини й усього організму до гіпоксії. Аналіз літератури з досліджень молекулярних механізмів дії пренатальної гіпоксії показав, що основою гіпоксичних уражень головного мозку новонароджених $€$ каскад біохімічних і молекулярних процесів, що призводять до ексайтотоксичності, окиснювального та нітрозуючого стресів і запалення. Одночасно з цим за гіпоксії починають функціонувати й компенсаторно-пристосувальні механізми, що підвищують стійкість організму до дефіциту кисню.

В огляді особливу увагу приділено обговоренню даних щодо ролі молекулярних детермінант ендогенної нейропротекції, таких як HSP70 і HIF-1 $\alpha$. Транскрипційна система HIF-1 є ключовим регулятором адаптивних механізмів відповідей на гіпоксію на локальному та системному рівнях. Зміни в експресії генів HIF-1 у пренатальному розвитку запускають епігенетичні механізми, що призводять до негативних змін у розвитку нервової системи.

Важливим компонентом системи ендогенної нейропротекції є сімейство білків теплового шоку HSP70, які сприяють широкому спектру процесів фолдингу, рефолдингу білків, мембранній транслокації органелярних і секреторних білків, а також здійснюють контроль за активністю регуляторних білків. Вплив HSP на стабілізацію HIF-1 забезпечує активацію процесів проліферації, апоптозу, ангіогенезу за умов гіпоксії.

Білки HSP70 / HIF-1 $\alpha$ - системи можуть бути специфічними мішенями для впливу фармакологічних агентів з метою регуляції процесів адаптації організму до гіпоксії. Тому пошук нових ефективних нейропротекторних засобів повинен бути спрямований на активацію HSP70/HIF-1 $\alpha$-системи та використання агентів, здатних забезпечувати модуляцію генів, що кодують синтез білків HSP70 і HIF- $1 \alpha$.

Ключові слова: пренатальна гіпоксія, ендогенна нейропротекція, білки теплового шоку HSP70,

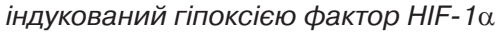

\section{И. Ф. Беленичев, Е. Г. Алиева \\ Новые мишени фармакологической коррекции когнитивных расстройств в условиях пренатального действия гипоксии}

В обзоре представлены современные концепции механизмов повреждений клеток головного мозга в условиях пренатального воздействия хронической гипоксии. На основе современных данных о механизмах адаптации организма к состоянию гипоксии предлагаются новые перспективные направления поиска эффективных лекарственных средств для фармакологической коррекции последствий пренатальной гипоксии. Пренатальная гипоксия является наиболее распространенной причиной смертности и инвалидности новорожденных детей. Пренатальная гипоксия приводит к значительным изменениям в развитии когнитивных функций в постнатальном периоде жизни, которые базируются на морфологических изменениях в структурах мозга, участвующих в обучении и памяти.

Результаты исследований последних лет внесли большой вклад в раскрытие механизмов формирования состояния гипоксии различного генеза и индуцируемых ею нарушений метаболических и функциональных процессов на уровне клетки и субклеточных структур. Определен ряд морфофункциональных детерминант (специфические рецепторы, регуляторные белки, внутриклеточные ферменты, митохондриальные ионные каналы и т. д.), принимающих непосредственное участие в развитии срочной и долговременной адаптации клетки и всего организма к гипоксии. Анализ литературы по исследованиям молекулярных механизмов действия пренатальной гипоксии показал, что в основе гипоксических поражений головного мозга новорожденных лежит каскад биохимических и молекулярных процессов, приводящих к эксайтотоксичности, окислительному и нитрозирующему стрессу и воспалению. Одновременно с этим при гипоксии начинают функционировать и компенсаторно-приспособительные механизмы, повышающие устойчивость организма к недостатку кислорода.

Особое внимание в обзоре уделено обсуждению данных о роли молекулярных детерминант эндогенной нейропротекции, таких как HSP70 и HIF-1a. Транскрипционная система HIF-1 является ключевым регулятором адаптивных механизмов ответов на гипоксию на локальном и системном уровнях. Изменения в экспрессии генов HIF-1 в пренатальном развитии запускают эпигенетические механизмы, приводящие к негативным изменениям в развитии нервной системы.

Важным компонентом системы эндогенной нейропротекции является семейство белков теплового шока HSP70, которые способствуют широкому спектру процессов фолдинга, рефолдинга белков, мембранной транслокации органеллярных и секреторных белков, а также осуществляют контроль активности регуляторных белков. Влияние HSP на стабилизацию HIF-1 обеспечивает активацию процессов пролиферации, апоптоза, ангиогенеза в условиях гипоксии. 
Белки HSP70/HIF-1 $\alpha$-системы могут быть специфическими мишенями для воздействия фармакологических агентов с целью регуляции процессов адаптации организма к гипоксии. Поэтому поиск новых эффективных нейропротекторных средств должен быть направлен на активацию HSP70/HIF-1 $\alpha$-системы и использование агентов, способных обеспечивать модуляцию генов, кодирующих синтез белков HSP70 и HIF-1 $\alpha$.

Ключевые слова: пренатальная гипоксия, эндогенная нейропротекция, белки теплового шока HSP70, индуцированный гипоксией фактор HIF-1 $\alpha$

\section{F. Belenichev, E. G. Aliyeva \\ New targets for pharmacological correction of cognitive disorders in prenatal hypoxia action}

The review presents modern concepts of the mechanisms of brain cells damage in the conditions of prenatal action of the chronic hypoxia. Based on modern data of the adaptation mechanisms of an organism to the hypoxia state, new perspective directions for the search of effective drugs are proposed for the pharmacological correction of the prenatal hypoxia effects. Prenatal hypoxia is the most common cause of the newborns death and disability. Prenatal hypoxia leads to significant changes in the development of cognitive functions in the postnatal period of life, which are based on morphological changes in the brain structures involved in learning and memory.

The results of recent years studies have made a great contribution to the disclosure of the formation mechanisms of a hypoxia state of different genesis and the metabolic and functional processes induced by it at the level of a cell and subcellular structures.

A range of morphological and functional determinants (specific receptors, regulatory proteins, intracellular enzymes, mitochondrial ion channels, etc.) have been identified. They are directly involved in the development of immediate and long-term adaptation of the cell and the whole organism to hypoxia. An analysis of the literature as to studies of the molecular mechanisms of the prenatal hypoxia action showed that the basis of hypoxic damage of the newborn brain is a cascade of biochemical and molecular processes leading to excitotoxicity, oxidative and nitrosating stress and inflammation. At the same time, during hypoxia, compensatory-adaptive mechanisms begin to function, increasing the body's resistance to oxygen deficiency.

In the review special attention was paid to the discussion as to the role of endogenous neuroprotection molecular determinants, such as HSP70 and HIF-1 $\alpha$. The HIF-1 transcriptional system is a key regulator of adaptive mechanisms of responses to hypoxia at the local and systemic levels. Changes in the expression of HIF-1 gene in prenatal development trigger the epigenetic mechanisms leading to negative changes in the nervous system development.

An important component of the endogenous neuroprotective system is the HSP70 heat shock proteins family, which contributes to a wide range of processes of protein folding, refolding, membrane translocation of organellar and secretory proteins, and also controls the activity of regulatory proteins. The effect of HSP on the HIF-1 stabilization provides activation of processes of proliferation, apoptosis and angiogenesis in conditions of a hypoxia.

Proteins HSP70/HIF-1 $\alpha$-system may be specific targets for exposure of pharmacological agents to regulate of the organism's adaptation for hypoxia.

Therefore, the search of the new effective neuroprotective agents should be aimed to activation of HSP70/ HIF- $1 \alpha$-system and using of agents capable for providing of modulation of genes encoding the synthesis of HSP70- and HIF-1a- proteins.

Key words: prenatal hypoxia, endogenous neuroprotection, heat shock proteins HSP70, hypoxiainduced factor HIF-1 $\alpha$

Прийнята до друку: 4 вересня 2019 р.

Надійшла: 29 липня 2019 р.

Контактна особа: Бєленічев Ігор Федорович, професор, кафедра фармакології та медичної рецептури, Запорізький державний медичний університет, буд. 31, вул. Сталеварів, м. Запоріжжя, 69035. Тел.: + 380612342741. 